\title{
УДК 648.18
}

\section{THERMODYNAMIC ASPECTS OF FORMATION OF SPINNEL STRUCTURES IN THE SYNTHESIS OF PIGMENTS OF BLUE GAMMA WITH THE USE OF A WASTE CATALYST ACM ТЕРМОДИНАМІЧНІ АСПЕКТИ УТВОРЕННЯ ШПНЕЛЬНИХ СТРУКТУР ПРИ СИНТЕЗІ ПІГМЕНТІВ БЛАКИТНОЇ ГАМИ С ВИКОРИСТАННЯМ ВІДПРАЦЬОВАНОГО КАТАЛІЗАТОРА АКМ}

Ivanyuk E.V. / Іванюк O.B. c.t.s., as.prof. / к.m.н., доu. ORCID: 0000-0003-4112-837x

Suprunchuk V.I. / Супрунчук B.I. c.t.s., as.prof. / к.m.н., доu.

ORCID: 0000-0002-1148-6451

Osmuk M.P./ Осьмук М.П. $\mathrm{MSc} / \mathrm{Mazicmp}$ National Technical University of Ukraine "Igor Sikorsky Kyiv Polytechnic Institute" 03056, Kyiv, Prosp.Peremohy, 37, building 4 Національний технічний університет Украӥни «Київський політехнічний інститут ім. Ігоря Сікорського», м.Київ, просп. Перемоги 37, корпус 4

Abstract. The thermodynamic substantiation of spinel formation processes of spin-forming and colour-forming pigment structures using the method of sequentially parallel reactions and the concept of energy and entropy of the cation of tetra- into octahedral cavities of the oxygen frame of a spinel is carried out. The possibility of using the waste catalyst of AKM in the processes of synthesis of inorganic pigments as the basic raw material for replacement of oxides of cobalt (II) and aluminum (III) in charge compositions of pigments of blue-green gamma is proved.

Key words: thermodynamic analysis, spinel, octahedral frame, energy of ordering, entropy of ordering, Gibbs energy of spinel formation, waste catalyst, inorganic pigments

Introduction. Inorganic pigments, which include industrial waste, are synthesized in various oxide systems, namely: green and blue $\mathrm{Cr}_{2} \mathrm{O}_{3}-\mathrm{CoO}-\mathrm{ZnO}-$ $\mathrm{Al}_{2} \mathrm{O}_{3}$, brown $\mathrm{Fe}_{2} \mathrm{O}_{3}-\mathrm{ZnO}-\mathrm{Al}_{2} \mathrm{O}_{3}-\mathrm{MgO}$, ocher $\mathrm{Fe}_{2} \mathrm{O}_{3}-\mathrm{Cr}_{2} \mathrm{O}_{3}-\mathrm{ZnO}-\mathrm{Al}_{2} \mathrm{O}_{3}$ [1].

The object of the study is spent cobalt-containing ACM-type hydrogenation catalysts used in the processes of hydrotreating of natural gas and petroleum products from sulfur compounds, technological processes of ammonia production and methanol synthesis. The possibility of its use in the processes of synthesis of inorganic pigments of blue and blue-green colors has been clarified. This catalyst has, in accordance with the specifications, the composition, mass.\%: $\mathrm{Al}_{2} \mathrm{O}_{3}-(78-82)$, $\mathrm{CoO} \geq 4.5, \mathrm{MoO}_{3} \geq 12, \mathrm{Fe}_{2} \mathrm{O}_{3} \leq 0.2$.

Blue pigments of varying intensities and shades are synthesized mainly using cobalt (III) oxide, which decomposes (at temperatures above $1223 \mathrm{~K}$ ) to cobalt (II) oxide and can form, depending on the charge composition of the pigments, chromophore compounds of different types: simple spinels of $\mathrm{Co}[\mathrm{Al}]_{2} \mathrm{O}_{4}$, inverted $\mathrm{Al}[\mathrm{CoAl}] \mathrm{O}_{4}$, or solid solutions of spinels (Co $\left.\mathrm{Zn}\right)[\mathrm{Al}]_{2} \mathrm{O}_{4}$.

Main text. The relatively high content of cobalt (II) oxide and aluminum (III) oxide in the spent catalyst of the ACM determines its use as a basic raw material for 
the replacement of pure cobalt and aluminum oxides in the pigments of blue pigments.

The color gradient of the synthesized pigments is formed under the influence of many factors. The main ones are: the composition of the spinel formed, the ratio of the chromophore metals in the crystal lattice of the spinel due to the formation of solid solutions, the distribution of metal-chromophore cations between the tetra- and octahedral cells of the oxygen frame of the crystalline spinel lattice. Thermodynamic analysis (with subsequent experimental verification) of spinel-type chromophore compounds formation in the system $\mathrm{Cr}_{2} \mathrm{O}_{3}-\mathrm{Co}_{2} \mathrm{O}_{3}-\mathrm{ZnO}-\mathrm{Al}_{2} \mathrm{O}_{3}$ was performed in order to identify the conditions of color formation of pigments synthesized with equivalent replacement of oxides in the charge composition of the spent catalyst ACM.

The concept of energy $(\delta E)$ and entropy $(\delta S)$ of the transition of cations from the tetrahedral to the octahedral position of the oxygen frame of the crystalline spinel lattice was used as the basis for thermodynamic analysis. The energies and entropies of the transition of cations into octahedral positions characterize the degree of inversion (disordering) of spinel. To calculate the ordering of the spinel structures formed, the paper proposes the use of systematic data on energy $(\delta E)$ and entropy $(\delta S)$ of the transition of cations into the octahedral state of spinels in [2-4].

When calculating the ordering of mixed spinels, using the concepts of energy and entropy of transition, the principle of thermodynamic independence of sequentially parallel processes of transition (of both two- and trivalent cations) from tetrahedral to octahedral positions of the oxygen spinel frame was used. The ordering of the cations in the crystal lattice of spinels was described by the following seriesparallel reactions of the type:

$$
\begin{aligned}
& A^{\prime}+[B] \Leftrightarrow\left[A^{\prime}\right]+B, \\
& A^{\prime \prime}+[B] \Leftrightarrow\left[A^{\prime \prime}\right]+B,
\end{aligned}
$$

where the square brackets denote the tetrahedral position of the cation in the crystalline spinel frame.

The general stoichiometric formula of complex mixed spinel formed by simple inversions takes the following form: $A_{1-n-x}^{\prime} A_{n-y}^{\prime \prime} B_{x+y}\left[A_{x}^{\prime} A_{y}^{\prime \prime} B_{2-x-y}\right] O_{4}$, where x, y - a measure of the depth of reactions (1) and (2). Given that the equilibrium constant of the reaction is defined as $\ln K=-\Delta G /(R T)$, we define the Gibbs energy of the cation transition from tetra- to octahedral positions of the oxygen spinel frame as $\delta \mathrm{G}^{\prime}=\delta \mathrm{E}^{\prime}$ $T \delta S^{\prime}, \delta G^{\prime \prime}=\delta E^{\prime \prime}-T \delta S^{\prime \prime}$. The transition energy $\delta \mathrm{E}^{\prime}$ by reaction (1) was calculated by the formula $\delta \mathrm{E}^{\prime}=\mathrm{E}_{\mathrm{A}}-\mathrm{E}_{\mathrm{B}}{ }^{\prime}, \mathrm{kJ} / \mathrm{mol}$. The entropy values of the transition $\delta \mathrm{S}^{\prime}$ to the octahedral state by reaction (1) are calculated by the formula $\delta S^{\prime}=S_{A}-S_{B}{ }^{\prime}, \mathrm{J} /(\mathrm{mol} \mathrm{K})$. The value of the transition energy $\delta E^{\prime \prime}$ into the octahedral state by reaction (2) is calculated by the formula $\delta E^{\prime \prime}=E_{A}-E_{B}$ ", $\mathrm{kJ} / \mathrm{mol}$. The entropy values of the transition $\delta S^{\prime \prime}$ to the octahedral reaction state (2) are calculated by the formula $\delta S^{\prime \prime}=$ $S_{A}-S_{B}^{\prime \prime}, \mathrm{J} /(\mathrm{mol} \mathrm{K})$.

Accordingly, the system of equations of isotherms of successive reactions (1) and (2) can be represented in the following form:

$[x(x+y)] /[(1-n-x)(2-x-y)]-\exp \left[\left(S_{A}{ }^{\prime}-S_{B}\right) / R-\left(E_{A}{ }^{\prime}-E_{B}\right) /(R T)\right]=0$, 
$[y(x+y)] /[(n-x)(2-x-y)]-\exp \left[\left(S_{A}^{\prime \prime}-S_{B}\right) / R-\left(E_{A}^{\prime \prime}-E_{B}\right) /(R T)\right]=0$.

After calculating the values of $x, y$ and establishing the degree of ordering of the two- and trivalent cations at different positions of the oxygen lattice of the crystal lattice, the enthalpy of formation $\left(\Delta H_{f}\right)$ and entropy of formation $(\Delta S)$ of spinel [2]: $A_{1-n-x}^{\prime} A_{n-y}^{\prime \prime} B_{x+y}\left[A_{x}^{\prime} A_{y}^{\prime \prime} B_{2-x-y}\right] O_{4}$, considering the ion ordering, the cations of the two and trivalent metals are in octahedral or tetrahedral positions of the oxygen frame.

The effect of temperature on the value of $\Delta G$ and the probability of formation of mixed spinels from simple oxides is expressed by the equation: $\Delta G=\Delta H_{f}-T \Delta S$, де $\Delta H_{f}=\left(-38,7+0,613 \cdot \delta H\left(\delta H=-(1-x) \cdot E\left(A^{\prime}\right)+(1-x) \cdot E\left(A^{\prime \prime}\right)\right]-\left[x \cdot E\left(B^{\prime}\right)+x \cdot E\left(B^{\prime \prime}\right)\right]\right), \Delta S$ $\left.=-\delta S=-(1-x) \cdot S\left(A^{\prime}\right)+(1-x) \cdot S\left(A^{\prime \prime}\right)\right]-\left[x \cdot S\left(B^{\prime}\right)+x \cdot S\left(B^{\prime \prime}\right)\right]$.

For the selected $\mathrm{Cr}_{2} \mathrm{O}_{3}-\mathrm{CoO}-\mathrm{ZnO}-\mathrm{Al}_{2} \mathrm{O}_{3}$ oxide system, the temperature and concentration dependence of the enthalpy, entropy, and Gibbs energy of the spinel spin formation process were calculated according to the ion distribution equations: $[\mathrm{Co}] \mathrm{O}+[\mathrm{Al}]_{2} \mathrm{O}_{3}=\mathrm{Co}_{1-x} \mathrm{Al}_{y}\left[\mathrm{Co}_{x} \mathrm{Al} l_{2-y}\right],[\mathrm{Co}] \mathrm{O}+[\mathrm{Cr}]_{2} \mathrm{O}_{3}=\mathrm{Co}_{1-x} \mathrm{Cr}_{y}\left[\mathrm{Co}_{x} \mathrm{Cr}_{2-y}\right]$ presented in Tab. 1.

Table 1

Enthalpy, entropy, and Gibbs energy of mixed spinel formation reactions as a function of temperature

\begin{tabular}{|c|c|c|c|c|c|c|c|}
\hline \multirow{3}{*}{ 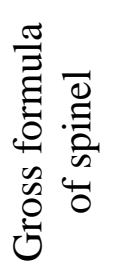 } & \multirow{3}{*}{ 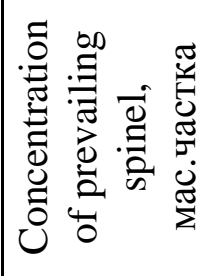 } & \multicolumn{6}{|c|}{ Synthesis temperature, $\mathrm{K}$} \\
\hline & & \multicolumn{3}{|c|}{1623} & \multicolumn{3}{|c|}{1500} \\
\hline & & $\Delta \mathrm{H}_{\mathrm{f}}$ & $\Delta \mathrm{S}$ & $\Delta G$ & $\Delta \mathrm{H}_{\mathrm{f}}$ & $\Delta \mathrm{S}$ & $\Delta \mathrm{G}$ \\
\hline \multirow{9}{*}{ 䓠 } & 0,1 & $-16,57$ & 13,25 & $-38,1$ & $-16,66$ & 13,25 & $-36,5$ \\
\hline & 0,2 & $-16,73$ & 13,26 & $-38,3$ & $-16,86$ & 13,28 & $-36,8$ \\
\hline & 0,3 & $-16,94$ & 13,31 & $-38,5$ & $-17,05$ & 13,32 & -37 \\
\hline & 0,4 & $-17,2$ & 13,35 & $-38,9$ & $-17,31$ & 13,36 & $-37,4$ \\
\hline & 0,5 & $-17,5$ & 13,36 & $-39,2$ & $-17,6$ & 13,38 & $-37,7$ \\
\hline & 0,6 & $-17,83$ & 13,42 & $-39,6$ & $-17,94$ & 13,44 & $-38,1$ \\
\hline & 0,7 & $-18,22$ & 13,48 & $-40,1$ & $-18,33$ & 13,48 & $-38,6$ \\
\hline & 0,8 & $-18,69$ & 13,55 & $-40,7$ & $-18,8$ & 13,56 & $-39,1$ \\
\hline & 0,9 & $-19,33$ & 13,64 & $-41,5$ & $-19,34$ & 13,64 & $-39,8$ \\
\hline \multirow{9}{*}{ 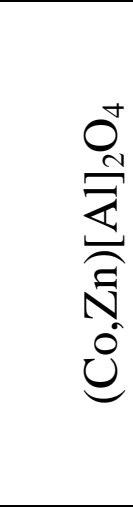 } & 0,1 & $-18,38$ & 11,86 & -36 & $-18,48$ & 11,89 & $-36,3$ \\
\hline & 0,2 & $-20,37$ & 10,53 & $-36,5$ & $-20,5$ & 10,53 & $-36,3$ \\
\hline & 0,3 & $-22,44$ & 9,18 & $-36,8$ & $-22,57$ & 9,2 & $-36,35$ \\
\hline & 0,4 & $-24,45$ & 7,83 & $-36,9$ & $-24,65$ & 7,86 & $-36,4$ \\
\hline & 0,5 & $-26,53$ & 6,49 & $-37,1$ & $-26,72$ & 6,52 & $-36,5$ \\
\hline & 0,6 & $-28,57$ & 5,16 & $-37,2$ & $-28,79$ & 5,17 & $-36,55$ \\
\hline & 0,7 & $-30,58$ & 3,81 & $-37,4$ & $-30,86$ & 3,84 & $-36,62$ \\
\hline & 0,8 & $-32,54$ & 2,46 & $-37,5$ & $-32,89$ & 2,5 & $-36,54$ \\
\hline & 0,9 & $-34,24$ & 1,09 & $-37,6$ & $-34,74$ & 1,53 & -37 \\
\hline
\end{tabular}

Authoring

As can be seen from Tab. 1, the Gibbs energy value for complex spines 
$\mathrm{Co}_{1-x} \mathrm{Al}_{y}\left[\mathrm{Co}_{x} \mathrm{Al}_{2-y}\right], \mathrm{Co}_{1-x} \mathrm{Cr}_{y}\left[\mathrm{Co}_{x} \mathrm{Cr}_{2-y}\right]$, which can be formed, becomes significantly negative and close. This indicates that there is a significant likelihood of mixing simple spinels of $\mathrm{Co}[\mathrm{Al}]_{2} \mathrm{O}_{4}, \mathrm{Co}[\mathrm{Cr}]_{2} \mathrm{O}_{4}, \mathrm{Zn}[\mathrm{Al}]_{2} \mathrm{O}_{4}, \mathrm{Zn}[\mathrm{Cr}]_{2} \mathrm{O}_{4}$ into a complex mixed with the formation of continuous series of solid solutions, which promotes the formation of shades colors in the synthesis of blue and blue-green pigments.

Thus, for mixed spinel $\mathrm{CoZn}[\mathrm{Al}]_{2} \mathrm{O}_{4}$ blue at $1623 \mathrm{~K}$, the Gibbs energy value changes from minus $36 \mathrm{~kJ} / \mathrm{mol}$ to minus $37.6 \mathrm{~kJ} / \mathrm{mol}$ with a change in the concentration of $\mathrm{Co}[\mathrm{Al}]_{2} \mathrm{O}_{4}$ from 0.2 to 0.8 molar particles in the composition folding spinel. This indicates that the formation of blue shades of pigments is the result not only of simple physical mixing of colors, but also the formation of mixed cobaltalumina-zinc spinel. And for the pigment with the optimal composition of mass.\%: $\mathrm{ACM}$ - 50, ZnO - 50, and termodinamic parameters $\Delta G=-37.5 \mathrm{~kJ} / \mathrm{mol} \mathrm{n}\left(\mathrm{Co}[\mathrm{Al}]_{2} \mathrm{O}_{4}\right)$ $=0.8$ and cationic distribution: $\mathrm{Co}_{0,867} \mathrm{Zn}_{0,13} \mathrm{Al}_{0.003}\left[\mathrm{Co}_{0,133} \mathrm{Zn}_{1,07} \mathrm{Al}{ }_{1.797}\right]_{\mathrm{O}_{4}}$, it can be argued that the formation of complex mixed spinel using the spent ACM catalyst as a raw material for the replacement of pure cobalt and aluminum oxides.

As the synthesis temperature increases from $1500 \mathrm{~K}$ to $1623 \mathrm{~K}$ and a constant value of $\mathrm{n}=0.8$ the $\Delta G$ value decreases from minus $36.54 \mathrm{~kJ} /$ mol to minus $37.5 \mathrm{~kJ}$ / mol, which corresponds to the stabilization of the mixed spinel structure of the pigments with increasing synthesis temperature. The tendency to decrease the value of $\Delta G$ with increasing synthesis temperature can be traced to the entire concentration field of mixed spinel.

Conclusions. Thus, thermodynamic analysis of cobalt-alumina-chromium and cobalt-alumina-zinc oxide systems formed by the use of the activated catalyst ACM as a raw material component for the synthesis of inorganic pigments showed that in the processes of synthetic firing, not only changes in the formation formation of solid solutions and this causes the formation of a color gradient of pigments from blue to blue-green. At the same time, almost complete replacement of cobalt and aluminum oxides in the pigment batch is achieved, with the activated ACM, which helps to solve the problem of environmental pollution, which meets the principles of sustainable chemistry.

\section{References:}

1. Визир В.А., Мартынов М.А., Керамические краски.-К.: Техніка,1964.$252 \mathrm{c}$.

2. Резницкий Л.А. Химическая связь и превращения оксидов. -М.: Изд-во МГУ, 1991.-168c.

3. Резницкий Л.А. Энергии предпочтения ионов и теплоты образования шпинелей / Вестник МГУ, серия 2.-М.: Химия.- 1977.-т.18.-№ 1.-С.66-71.

4. Резницкий Л.А. Кристаллоэнергетика оксидов. -М.: Изд-во МГУ, 1998.$187 \mathrm{c}$.

\section{References:}

1. VizirV.A. Martinov M.A. Keramicheskie kraski.-K: Technika.1964.-252 str.

2. Reznickiy L.A. Khimicheskaya svyaz i prevrachenie oksidov.-M:Izdatelstvo MGU, 1991.198 str. 
3. Reznickiy L.A Energii predpochteniya ionov i teploty obrazovaniya shpineley/ Vesnik MGU, seriya 2, .-M. Khimiya.-1977.-t.18.-№1 .str. 66-71/

4. Reznickiy L.A. Kristoloenergetika oksidov.-M:Izdatelstvo MGU, 1998.-187 str.

Анотація. $B$ роботі проведено термодинамічне обгрунтування процесів шпінелеутворення колоьороутворюючих шпінельних структур пігментів з використанням методу послідовно-паралельних реакиій та поняття енергія та ентропія розупорядкування катіонів із тетра- в октаедричні порожнини оксигенного каркасу шпінелі. Доведено можливість використання відпрацьованого каталізатора АКМ в прочесах синтезу неорганічних пігментів як базової сировини для заміни оксидів кобальту(II) та алюмінію(III) в шихтових складах пігментів синьо-зеленої гами та утворення безперервного ряду твердих розчинів шпінелей, щз зменшує техногенне навантаження на навколишнє середовище.

Ключові слова: термодинамічний аналіз, шпінель, октаедричний каркас, енергія розупорядкування, ентропія розупорядкування, енергія Гібба утворення шпінелі, відпрацьований каталізатор, неорганічні пігменти

Стаття відправлена: 3.10.2019 р. (C) E.V.Ivanyuk 